\title{
Progress of the COVID-19 vaccine effort: viruses, vaccines and variants versus efficacy, effectiveness and escape
}

\author{
John S. Tregoning (D), Katie E. Flight, Sophie L. Higham, Ziyin Wang (D) \\ and Benjamin F. Pierce
}

Abstract | Where 2020 saw the development and testing of vaccines against severe acute respiratory syndrome coronavirus 2 (SARS-CoV-2) at an unprecedented pace, the first half of 2021 has seen vaccine rollout in many countries. In this Progress article, we provide a snapshot of ongoing vaccine efficacy studies, as well as real-world data on vaccine effectiveness and the impact of virus variants of concern. Where they have been deployed in a high proportion of the adult population, the currently approved vaccines have been extremely effective in preventing COVID-19, particularly severe disease. Nonetheless, there are still significant challenges in ensuring equitable vaccine access around the globe and lessons that can be learned for controlling this pandemic and for the next pandemic.

Fifteen months on from the administration of the first experimental COVID-19 vaccine doses to humans in March 2020, there is now a global race against the causative virus severe acute respiratory syndrome coronavirus 2 (SARS-CoV-2) to deploy vaccines to control the pandemic ${ }^{1}$, with differing levels of vaccine rollout in different countries (Our World in Data). Despite authorization having been granted for multiple vaccines, as the ongoing global outbreaks demonstrate, the pandemic is far from over. Vaccination, in combination with non-pharmaceutical interventions, is the best way to control the pandemic. In this regard, we are fortunate that there is now a formidable toolkit of potential vaccines available: of the 322 candidate vaccines that have been proposed so far (July 2021), 99 are in clinical testing, 25 have reached phase III efficacy studies and 18 have received some form of approval for use. However, achieving global vaccine coverage remains a major hurdle; this is not just a matter of equity but is also an important part of the process to control the virus. SARS-CoV-2 continues to evolve under immune selective pressure, and while transmission levels remain high, there is an increased likelihood of vaccine escape variants evolving. In this Progress article, we cover recent developments in COVID-19 vaccines since the start of their deployment in late 2020/early 2021, including real-world data on vaccine effectiveness and the impact of viral variants.

\section{The current vaccine landscape}

Data from several phase III vaccine efficacy trials were reported at the end of 2020 , leading to the approval and rollout of these vaccines. The following organizations have reported efficacy data for their vaccines as summarized in TABLE 1: Pfizer-BioNTech ${ }^{2}$, Moderna $^{3}$, AstraZeneca-University of Oxford $^{4}$, Johnson \& Johnson ${ }^{5}$, Gamaleya ${ }^{6}$, Sinovac Biotech ${ }^{7}$, Sinopharm $^{7}$, Novavax $^{8}$ and Bharat Biotech ${ }^{9}$. As of 14 June 2021, each of these vaccines, except for the Novavax vaccine, had been approved for rollout to adults and, in some cases, to adolescents through a range of approval processes depending on the region and regulatory agency. This situation remains fluid, and importantly, the publication of the first wave of efficacy data and the first vaccine approvals were not the end of the clinical trial phase for COVID-19 vaccines. Ongoing vaccine trials test the efficacy of new vaccines in the face of an evolving virus; furthermore, they increase options for globally dispersed manufacturing of sufficient vaccine doses for global use and strengthen the data for novel vaccine platforms that could be of use in future pandemics. As this is a rapidly moving space, the best way to stay abreast of the vaccine trials is through live documents, such as the COVID-19 vaccine tracker from the London School of Hygiene and Tropical Medicine.

Within this larger list of ongoing studies, a smaller number of vaccines are in phase III clinical trials that are yet to release data: Inovio (DNA, ClinicalTrials. gov identifier NCT04336410), AnGes (DNA, NCT04655625), ReiThera (gorilla adenovirus, NCT04791423), the Chinese Academy of Medical Sciences (inactivated virus, NCT04412538), the Research Institute for Biological Safety Problems, Kazakhstan (QazCovid; inactivated virus, NCT04691908), Shifa (inactivated virus, NCT04526990), the Center for Genetic Engineering and Biotechnology, Cuba (CIGB-66; peptide, RPCEC00000345), Clover (peptide, NCT04672395), COVAXX (peptide, NCT04545749), the Finlay Institute, Cuba (peptide, RPCEC00000332), Sanofi-GlaxoSmithKline (adjuvanted protein, NCT04904549), VECTOR (peptide, NCT04780035) and Medicago (plant-derived virus-like particle, NCT04636697). We anticipate that some of the candidate vaccines currently in phase III trials will become available for wider use in quarters 3 and 4 of 2021, which will be important in stemming further waves of the pandemic and increasing vaccination rates in lower-income countries.

However, it should also be noted that some fairly high-profile vaccine programmes may not enter phase III efficacy studies. In collaboration with IAVI, Merck developed the viral-vectored COVID-19 vaccine V590 (REF. ${ }^{10}$ ). Merck also acquired a second COVID-19 vaccine through the buyout of Themis, the company responsible for producing the V591 (live viral vector) vaccine. However, the development of both V590 and V591 
Table 1 | Reported COVID-19 vaccine efficacy data from phase III trials

\begin{tabular}{|c|c|c|c|c|c|c|c|c|c|}
\hline $\begin{array}{l}\text { Vaccine } \\
\text { manufacturer } \\
\text { (vaccine name) }^{\mathrm{a}}\end{array}$ & Platform & $\begin{array}{l}\text { Clinical } \\
\text { trial } \\
\text { regime }\end{array}$ & $\begin{array}{l}\text { Total } \\
\text { trial } \\
\text { size }\end{array}$ & Efficacy & $\begin{array}{l}\text { End point } \\
\text { measure }\end{array}$ & Eligibility & $\begin{array}{l}\text { Duration of } \\
\text { follow up for } \\
\text { phase III trial }\end{array}$ & $\begin{array}{l}\text { Circulating } \\
\text { genotypes at } \\
\text { location and } \\
\text { time of trial }\end{array}$ & $\begin{array}{l}\text { Results by } \\
\text { severity }\end{array}$ \\
\hline $\begin{array}{l}\text { Moderna } \\
(\text { (mRNA-1273) }\end{array}$ & mRNA & $\begin{array}{l}2 \text { doses } \\
\text { (28 days } \\
\text { apart) }\end{array}$ & 30,420 & $94 \%$ & $\begin{array}{l}\text { Symptomatic } \\
\text { COVID-19 } \\
\text { and positive } \\
\text { RT-PCR test } \\
\text { result }\end{array}$ & $\begin{array}{l}\geq 18 \text { years old } \\
\text { (12 years old } \\
\text { to younger } \\
\text { than } 18 \text { years } \\
\text { (NCT04649151) } \\
\text { and } 6 \text { months } \\
\text { old to younger } \\
\text { than } 12 \text { years } \\
\text { (NCT04796896)) }\end{array}$ & $\begin{array}{l}\text { Up to } \\
24 \text { months after } \\
\text { second dose } \\
\text { (NCT04470427) }\end{array}$ & $\begin{array}{l}\text { B.1.427/B.1.429 } \\
\text { and B.1.526 }\end{array}$ & $\begin{array}{l}100 \% \text { efficacy } \\
\text { against severe } \\
\text { disease }\end{array}$ \\
\hline \multirow{2}{*}{$\begin{array}{l}\text { AstraZeneca- } \\
\text { University of } \\
\text { Oxford (AZD1222 } \\
\text { (Vaxzevria, } \\
\text { also called } \\
\text { Covishield when } \\
\text { manufactured by } \\
\text { Sll under license)) }{ }^{4}\end{array}$} & \multirow[t]{2}{*}{$\begin{array}{l}\text { Viral } \\
\text { vector }\end{array}$} & $\begin{array}{l}2 \text { doses } \\
\text { (<6 weeks } \\
\text { apart) }\end{array}$ & \multirow[t]{2}{*}{17,178} & $55 \%$ & \multirow{2}{*}{$\begin{array}{l}\text { Symptomatic } \\
\text { COVID-19 } \\
\text { and positive } \\
\text { NAAT result }\end{array}$} & \multirow{2}{*}{$\begin{array}{l}\geq 18 \text { years } \\
\text { old }(\mathrm{WHO}) \\
\geq 40 \text { years } \\
\text { old and not } \\
\text { pregnant in UK }\end{array}$} & $\begin{array}{l}24 \text { months } \\
\text { after first dose } \\
\text { (NCT04516746) }\end{array}$ & \multirow{2}{*}{$\begin{array}{l}\text { B.1.1.7, } \\
\text { B.1.351, P.1, } \\
\text { B.1.427/B.1.429, } \\
\text { P.2, B.1.526 } \\
\text { and C.37 } \\
\end{array}$} & \multirow{2}{*}{$\begin{array}{l}100 \% \text { efficacy } \\
\text { against } \\
\text { hospitalization }\end{array}$} \\
\hline & & $\begin{array}{l}2 \text { doses } \\
\text { ( }>12 \text { weeks } \\
\text { apart) }\end{array}$ & & $\begin{array}{l}81 \% \\
\text { (Pooled } \\
\text { efficacy } \\
67 \% \text { ) }\end{array}$ & & & $\begin{array}{l}12 \text { months after } \\
\text { second dose } \\
\text { (NCT04400838, } \\
\text { NCT04536051 } \\
\text { and } \\
\text { NCT04516746) }\end{array}$ & & \\
\hline $\begin{array}{l}\text { Johnson \& Johnson b } \\
\text { (Ad26.COV2-S) }\end{array}$ & $\begin{array}{l}\text { Viral } \\
\text { vector }\end{array}$ & 1 dose & 44,325 & $66 \%$ & $\begin{array}{l}\text { Symptomatic } \\
\text { COVID-19 } \\
\text { and positive } \\
\text { RT-PCR test } \\
\text { result }\end{array}$ & $\geq 18$ years old & $\begin{array}{l}25 \text { months } \\
\text { (NCT04505722) } \\
\text { and } 27 \text { months } \\
\text { (NCT04614948) } \\
\text { after first dose }\end{array}$ & $\begin{array}{l}\text { B.1.351, P.1, } \\
\text { B.1.427/B.1.429, } \\
\text { P.2, B.1.526 and } \\
\text { C. } 37\end{array}$ & $\begin{array}{l}85.4 \% \text { efficacy } \\
\text { against } \\
\text { severe-critical } \\
\text { disease } \\
\text { occurring } \\
\geq 28 \text { days after } \\
\text { vaccination }\end{array}$ \\
\hline $\begin{array}{l}\text { Bharat Biotech } \\
\text { (Covaxin) }^{9}\end{array}$ & $\begin{array}{l}\text { Viral } \\
\text { vector }\end{array}$ & $\begin{array}{l}2 \text { doses } \\
\text { (28 days } \\
\text { apart) }\end{array}$ & 25,800 & $78 \%$ & $\begin{array}{l}\text { Symptomatic } \\
\text { COVID-19 } \\
\text { and positive } \\
\text { RT-PCR test } \\
\text { result at least } \\
14 \text { days after } \\
\text { second dose }\end{array}$ & $\begin{array}{l}\geq 18 \text { years old } \\
\text { ( } 2-18 \text { years old: } \\
\text { study ongoing) }\end{array}$ & $\begin{array}{l}12 \text { months after } \\
\text { second dose } \\
\text { (NCT04641481); } \\
\text { paediatric } \\
\text { cohort followed } \\
\text { up for } 9 \text { months } \\
\text { (NCT04918797) }\end{array}$ & $\begin{array}{l}\text { Phase III trial } \\
\text { began on } \\
16 \text { November } \\
2020 \text { and is } \\
\text { ongoing in India; } \\
\text { variants iden- } \\
\text { tified include } \\
\text { B.1.617.2 and } \\
\text { B.1.617.1 }\end{array}$ & $\begin{array}{l}100 \% \text { efficacy } \\
\text { against } \\
\text { hospitalization }\end{array}$ \\
\hline $\begin{array}{l}\text { Sinovac Biotech } \\
\text { (CoronaVac) }\end{array}$ & $\begin{array}{l}\text { Inacti- } \\
\text { vated } \\
\text { virus }\end{array}$ & $\begin{array}{l}2 \text { doses } \\
\text { (14 days } \\
\text { apart; } \\
14 \text { or } \\
28 \text { days } \\
\text { apart in } \\
\text { Chile) }\end{array}$ & $\begin{array}{l}2,300 \\
\text { (Chile); } \\
13,000 \\
\text { (Turkey); } \\
12,688 \\
\text { (Brazil) }\end{array}$ & $\begin{array}{l}\text { Multiple } \\
\text { studies in } \\
\text { different } \\
\text { countries: } \\
50.7 \% \\
\text { (Brazil), } \\
56.5 \% \\
\text { (Chile), 65\% } \\
\text { (Indonesia), } \\
78 \% \text { (Brazil) } \\
\text { and 91\% } \\
\text { (Turkey) }\end{array}$ & $\begin{array}{l}\text { Symptomatic, } \\
\text { virologically } \\
\text { confirmed } \\
\text { COVID-19 } \\
\text { occurring } \\
\text { from } 2 \text { weeks } \\
\text { after the } \\
\text { second dose } \\
\text { up to } 1 \text { year } \\
\text { after the first } \\
\text { dose }\end{array}$ & $\geq 18$ years old & $\begin{array}{l}12 \text { months } \\
\text { after first dose }\end{array}$ & P.1 and P.2 & $\begin{array}{l}51 \% \text { efficacy } \\
\text { against } \\
\text { symptomatic } \\
\text { SARS-CoV-2 } \\
\text { infection; } \\
100 \% \text { efficacy } \\
\text { against severe } \\
\text { disease; } \\
100 \% \text { efficacy } \\
\text { against hospi- } \\
\text { talization from } \\
14 \text { days after } \\
\text { second dose }\end{array}$ \\
\hline
\end{tabular}


Table 1 (cont.) | Reported COVID-19 vaccine efficacy data from phase III trials

\begin{tabular}{|c|c|c|c|c|c|c|c|c|c|}
\hline $\begin{array}{l}\text { Vaccine } \\
\text { manufacturer } \\
{\text { (vaccine name })^{\mathrm{a}}}^{\text {a }}\end{array}$ & Platform & $\begin{array}{l}\text { Clinical } \\
\text { trial } \\
\text { regime }\end{array}$ & $\begin{array}{l}\text { Total } \\
\text { trial } \\
\text { size }\end{array}$ & Efficacy & $\begin{array}{l}\text { End point } \\
\text { measure }\end{array}$ & Eligibility & $\begin{array}{l}\text { Duration of } \\
\text { follow up for } \\
\text { phase III trial }\end{array}$ & $\begin{array}{l}\text { Circulating } \\
\text { genotypes at } \\
\text { location and } \\
\text { time of trial }\end{array}$ & $\begin{array}{l}\text { Results by } \\
\text { severity }\end{array}$ \\
\hline $\begin{array}{l}\text { Novavax }^{b} \\
(\text { NVX-CoV2373) }\end{array}$ & $\begin{array}{l}\text { Protein } \\
\text { subunit }\end{array}$ & $\begin{array}{l}2 \text { doses } \\
\text { (21 days } \\
\text { apart) }\end{array}$ & $>15,000$ & $89 \%$ & $\begin{array}{l}\text { Symptomatic } \\
\text { COVID-19 } \\
\text { and positive } \\
\text { RT-PCR test } \\
\text { result at least } \\
7 \text { days after } \\
\text { second dose }\end{array}$ & $\begin{array}{l}\geq 18 \text { years old } \\
\text { (12-17 years } \\
\text { old: study } \\
\text { ongoing, } \\
\text { NCT04611802) }\end{array}$ & $\begin{array}{l}24 \text { months } \\
\text { after first dose } \\
\text { (NCT04611802) }\end{array}$ & $\begin{array}{l}\text { B.1.1.7, B.1.351, } \\
\text { B.1.427/B.1.429 } \\
\text { and B.1.526 }\end{array}$ & $\begin{array}{l}100 \% \text { efficacy } \\
\text { against severe } \\
\text { disease and } \\
\text { hospitalization }\end{array}$ \\
\hline
\end{tabular}

CDC, Centers for Disease Control and Prevention; FDA, Food and Drug Administration; NAAT, nucleic acid amplification test; RT-PCR, reverse transcriptionpolymerase chain reaction; SARS-CoV-2, severe acute respiratory syndrome coronavirus 2; SII, Serum Institute of India; WHO, World Health Organization.

${ }^{a}$ Vaccines in bold have been approved for use. ${ }^{\text {b }}$ Data extracted from interim analysis.

has been discontinued, owing to their poor immunogenicity ${ }^{11}$. The University of Queensland and the biotechnology company CSL also discontinued development of their protein subunit vaccine candidate (UQ-CSL v451). Phase I trials showed that the vaccine was well tolerated and elicited a robust immune response. However, trial participants also developed antibodies to the 'molecular clamp' used to stabilize the SARS-CoV-2 spike (S) protein ${ }^{12}$, which comprised S protein fragments from HIV-1 $\left(R_{E F}{ }^{13}\right)$. Antibodies to the molecular clamp were shown to interfere with HIV-1 tests, causing false-positive results, which halted the development of the vaccine ${ }^{12,13}$. Whereas the mRNA vaccines from Pfizer-BioNTech (BNT162b2) and Moderna (mRNA-1273) have shown high levels of efficacy, a third mRNA candidate vaccine, from CureVac (CVnCoV), demonstrated only $47 \%$ efficacy in interim analysis, which did not meet the trial success criteria ${ }^{14}$. It is not yet clear why $\mathrm{CVnCoV}$ was less protective than either BNT162b2 or mRNA-1273, but it is of note that unlike the mRNA used in the PfizerBioNTech vaccine or the Moderna vaccine, the CureVac mRNA does not contain the modified nucleoside pseudouridine instead of uridine, which may alter the way the vaccine itself is sensed ${ }^{15}$. The SanofiGlaxoSmithKline adjuvanted protein vaccine experienced a setback when the initial trial used too low a dose of antigen ${ }^{16}$, but following reformulation, this programme is ongoing with a phase III trial.

The approved vaccines use a range of different platforms (mRNA, viral vector, protein/peptide and inactivated virus). Comparisons of the relationship between efficacy and neutralizing and binding antibody titres in vitro across various vaccine platforms have been conducted ${ }^{17,18}$. These data suggest higher antibody responses to the mRNA vaccines and to the Novavax protein subunit vaccine than to the viral-vectored and inactivated virus vaccines. Dissecting why different vaccine platforms induce a different quality and/or quantity of immune response will be crucial to develop successful vaccine approaches for future pandemics. Efficacies ranging from $60 \%$ to $94 \%$ have been reported for the various vaccines, but owing to differences in trial design, end point measured, trial location, population studied and prevalence of SARS-CoV-2 variants at the time of the trial, it is not possible to make head-to-head comparisons between the different vaccine platforms. Although differences in how the clinical trials were set up make comparison between vaccines harder, having multiple approaches to reach the critical end goal of an effective vaccine is pragmatically more important than delaying studies to enable direct comparisons to be made, which could delay vaccine rollout and thereby contribute to increased deaths. The only valid way to compare vaccines directly is in head-to-head efficacy trials, which are unlikely to be undertaken owing to the number of trial participants required, the pre-existing efficacy data, the current level of vaccine rollout and levels of pre-existing immunity in the population. One approach to avoid difficulties of comparison between vaccine platforms for future pandemics would be to have pre-prepared (and standardized) trial protocols that could be adopted rapidly by multiple teams. In the absence of direct comparison, the next best thing is to compare the approved vaccines for effectiveness in the same population at the same time (see the next section). An additional challenge for assessing both the efficacy and the effectiveness of vaccines is the lack of published data, with many results having been made available through press releases rather than peer-reviewed articles.

\section{Vaccine effectiveness}

The efficacies for COVID-19 vaccines shown in TABLE 1 were calculated from clinical trials based on defined end points (which can differ between trials, even in terms of the definition of symptomatic disease). These values are important for the approval of vaccines, but they do not necessarily reflect the impact of vaccination 
in the real world, especially when clinical trials for vaccines have enrolled mostly younger, healthy adults compared to those most at risk of severe disease, and these trials occurred in the absence of some of the more recently reported SARS-CoV-2 variants. It is therefore important to understand the extent and duration of protection against infection or disease in all age groups and populations; in the case of COVID-19, this is particularly important given the higher risk of severe disease in older individuals (70 years of age and older). Vaccine effectiveness, which differs from vaccine efficacy, is the reduced risk of infection or disease among vaccinated individuals. This can be impacted by population-dependent effects of the vaccine as well as vaccination schedules and handling/administration of vaccines (FIG. 1).

In the UK, vaccination with BNT162b2 (Pfizer-BioNTech) or AZD1222

(AstraZeneca-University of Oxford) started on 3 December 2020. Since April 2021, the mRNA-1273 (Moderna) vaccine has also been available in the UK, but owing to the shorter time that this has been part of the vaccination schedule, there are as yet no vaccine effectiveness data for mRNA-1273 from the UK. Public Health England reported on the early impact and effectiveness of COVID-19 vaccination with BNT162b2 or AZD1222 in England in March 2021: vaccine effectiveness against death and hospitalization for either vaccine was estimated at $81 \%$ and $80 \%$, respectively ${ }^{19}$. In a study of the effectiveness of BNT162b2 or AZD1222 against symptoms in 156,930 adults between December 2020 and February 2021, vaccine effectiveness was $70 \%$ in participants aged 80 years or older after the first vaccine dose, increasing to $89 \% 14$ days after the second dose $^{20}$. In the same study, for participants aged 70 years or older, vaccine effectiveness against symptoms was $61 \%$ for BNT162b2 and $60 \%$ for AZD1222 28-34 days after first-dose vaccination. However, a potential limitation of these early estimates of vaccine effectiveness is that the controls were defined differently and thus odds ratios may be skewed. The studies were either test-negative designs (in which the control group is individuals within the study who have COVID-19-like symptoms but test negative for SARS-CoV-2) or based on a screening method (in which vaccination coverage in SARS-CoV-2-positive individuals is compared with the vaccination coverage in the general population from which the cases are derived). Using vaccination coverage as the control can produce more reliable information on vaccine effectiveness,

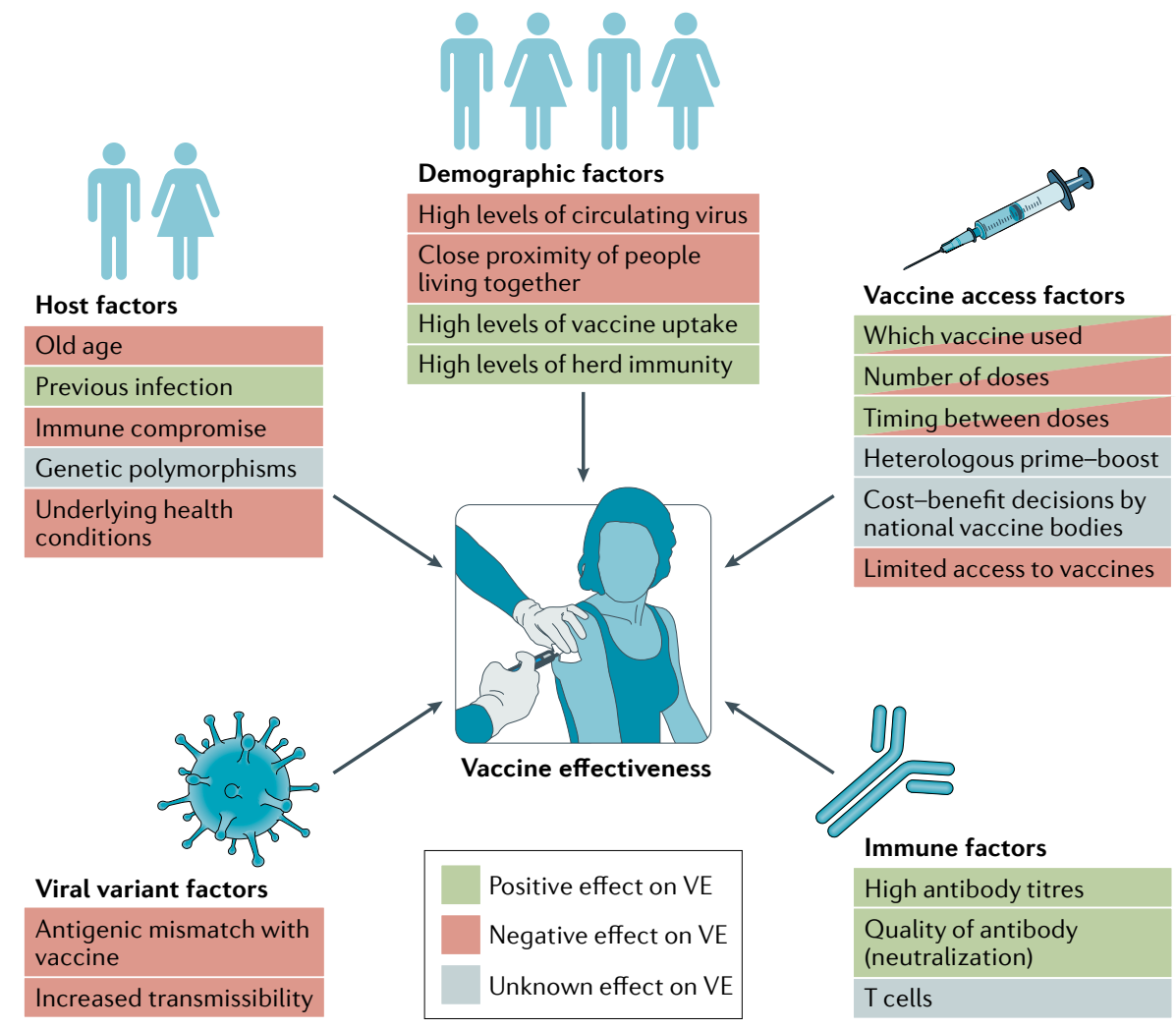

Fig. 1 | Factors influencing vaccine effectiveness. Multiple factors can increase or decrease vaccine effectiveness (VE) at both the individual level and the population level. such as the method used in the SIREN (SARS-CoV-2 Immunity and Reinfection Evaluation) study ${ }^{21}$.

In the UK, a decision was made on 30 December 2020 to delay the second vaccine dose to 12 weeks after the first dose, regardless of the vaccine administered. This was a pragmatic decision aiming to increase the number of individuals (particularly in high-risk groups) who would be afforded some immune protection from a first dose. The 12-week interval differed from the regime used in the efficacy trials for BNT162b2 and mRNA-1273, which gave doses at 3-week and 4-week intervals, respectively. There were concerns that immunity might wane rapidly after a single dose, that in more vulnerable individuals the response to a single dose might be insufficient and that lower levels of immunity might in some way accelerate the evolution of viral variants that could escape the immune response. These questions have yet to be fully answered and will continue to be important considerations especially as the UK continues to ease non-pharmaceutical interventions ${ }^{22}$. Unsurprisingly, both antibody responses ${ }^{23}$ and vaccine effectiveness ${ }^{24}$ are lower after a single dose of either BNT162b2 or mRNA-1273 than after two doses. Antibody levels following BNT162b2 vaccination do wane within 12 weeks following one dose $\mathrm{e}^{23}$. There is, however, protection from one vaccine dose, with vaccine effectiveness after a single dose of BNT162b2 of 91\% and after a single dose of AZD1222 of $88 \%{ }^{24}$. One advantage of delaying vaccination is that antibody responses to the second dose might be greater; the antibody response to BNT162b2 is greater in individuals aged 80 years or older when the vaccination gap is increased from 3 to 12 weeks ${ }^{25}$. Ultimately, the length of the dose interval comes down to a decision by national vaccine committees as to whether it is better to get a lower level of immune protection in a greater number of people or more protection in fewer people. This risk-benefit profile will change over time, especially once greater coverage has been achieved in the elderly, more at risk groups, but also in response to the emergence of new viral variants (TABLE 2). In June 2021, individuals aged 40 years or older in the UK were invited to schedule their second vaccination after 8 weeks rather than 12 weeks as cases of the Delta (B.1.617.2) variant increased. Another important factor that must be included in any risk-benefit calculations is the potential serious adverse effects associated with the vaccines (BOX 1). 
Table 2 | Reported impact of SARS-CoV-2 variants on vaccine efficacy and effectiveness

\begin{tabular}{|c|c|c|c|c|c|c|c|c|c|}
\hline \multirow{2}{*}{$\begin{array}{l}\text { SARS- } \\
\text { CoV-2 } \\
\text { variant } \\
\text { (also } \\
\text { known as) }\end{array}$} & \multirow{2}{*}{$\begin{array}{l}\text { First } \\
\text { detected }\end{array}$} & \multirow{2}{*}{$\begin{array}{l}\text { Key } \\
\text { mutations }\end{array}$} & \multirow{2}{*}{$\begin{array}{l}\text { Trans- } \\
\text { missibility }\end{array}$} & \multicolumn{6}{|c|}{ Vaccine-mediated protection } \\
\hline & & & & $\begin{array}{l}\text { AZD1222 } \\
\text { (AstraZeneca- } \\
\text { University of } \\
\text { Oxford) }\end{array}$ & $\begin{array}{l}\text { BNT162b2 } \\
\text { (Pfizer- } \\
\text { BioNTech) }\end{array}$ & $\begin{array}{l}\text { mRNA- } \\
1273 \\
\text { (Moderna) }\end{array}$ & $\begin{array}{l}\text { Ad26.COV2-S } \\
\text { (Johnson \& } \\
\text { Johnson) }\end{array}$ & $\begin{array}{l}\text { NVX- } \\
\text { CoV2373 } \\
\text { (Novavax) }\end{array}$ & $\begin{array}{l}\text { Corona } \\
\text { Vac } \\
\text { (Sinovac) }\end{array}$ \\
\hline $\begin{array}{l}\text { Wuhan } \\
\text { reference } \\
\text { strain }\end{array}$ & $\begin{array}{l}\text { China, } \\
\text { December } \\
2019\end{array}$ & $\begin{array}{l}\text { Reference } \\
\text { strain }\end{array}$ & $\begin{array}{l}\text { Reference } \\
\text { strain }\end{array}$ & $55-81 \%^{4}$ & $95 \%^{2}$ & $94.1 \%^{3}$ & $66 \%^{5,51}$ & $89 \%^{8}$ & $50-90 \%^{7}$ \\
\hline \multirow{4}{*}{$\begin{array}{l}\text { Alpha, } \\
\text { B.1.1.7 } \\
\text { (British/ } \\
\text { Kent; VOC } \\
\text { 202012/01; } \\
\text { 20B/501Y. } \\
\text { V1) }\end{array}$} & \multirow{4}{*}{$\begin{array}{l}\text { UK, } \\
\text { September } \\
2020\end{array}$} & $\begin{array}{l}\text { Y144 } \\
\text { deletion }\end{array}$ & \multirow{4}{*}{$\begin{array}{l}\sim 50 \% \text { increase } \\
\text { in comparison } \\
\text { with previously } \\
\text { circulating } \\
\text { strains }^{66}\end{array}$} & \multirow{4}{*}{$75 \%^{44}$} & \multirow{4}{*}{$90 \%{ }^{67}$} & \multirow{4}{*}{$\begin{array}{l}\text { Reductions } \\
\text { by a factor } \\
\text { of } 2.3-6.4 \\
\text { in titres of } \\
\text { neutralizing } \\
\text { antibodies }^{68}\end{array}$} & \multirow{4}{*}{$70 \%{ }^{45}$} & \multirow{4}{*}{$86 \%{ }^{65}$} & \multirow{4}{*}{ Unknown } \\
\hline & & N501Y & & & & & & & \\
\hline & & A570D & & & & & & & \\
\hline & & D614G & & & & & & & \\
\hline \multirow{2}{*}{$\begin{array}{l}\text { Beta, } \\
\text { B.1.351 } \\
\text { (South } \\
\text { African; } \\
\text { 20H/501Y. } \\
\text { V2) }\end{array}$} & \multirow{2}{*}{$\begin{array}{l}\text { South } \\
\text { Africa, } \\
\text { September } \\
2020\end{array}$} & N501Y & \multirow{2}{*}{$25 \%$ increase $^{69}$} & \multirow{2}{*}{$10 \%^{70}$} & \multirow{2}{*}{$75 \%{ }^{67}$} & \multirow{2}{*}{$\begin{array}{l}\text { Reduced } \\
\text { levels of } \\
\text { neutralizing } \\
\text { antibodies }^{68}\end{array}$} & \multirow{2}{*}{$\begin{array}{l}72 \% \text { efficacy } \\
\text { in the USA, } \\
66 \% \text { in Latin } \\
\text { America and } \\
57 \% \text { in South } \\
\text { Africa }^{45}\end{array}$} & \multirow{2}{*}{$60 \%{ }^{65}$} & \multirow{2}{*}{ Unknown } \\
\hline & & D614G & & & & & & & \\
\hline \multirow{4}{*}{$\begin{array}{l}\text { Gamma, P.1 } \\
\text { (B.1.1.28.1) }\end{array}$} & \multirow{4}{*}{$\begin{array}{l}\text { Japan/ } \\
\text { Brazil, } \\
\text { December } \\
2020\end{array}$} & E484K & \multirow{4}{*}{$\begin{array}{l}1.4-2.2 \\
\text { times more } \\
\text { transmissible }^{71}\end{array}$} & \multirow[t]{4}{*}{ Unknown } & \multirow{4}{*}{$\begin{array}{l}\text { No evidence } \\
\text { of reduced } \\
\text { protection }\end{array}$} & \multirow{4}{*}{$\begin{array}{l}\text { Reduced } \\
\text { levels of } \\
\text { neutralizing } \\
\text { antibodies }^{68}\end{array}$} & \multirow[t]{4}{*}{$68 \%^{45}$} & \multirow[t]{4}{*}{ Unknown } & \multirow[t]{4}{*}{$51 \%^{72}$} \\
\hline & & $\mathrm{K} 417 \mathrm{~N} / \mathrm{T}$ & & & & & & & \\
\hline & & N501Y & & & & & & & \\
\hline & & D614G & & & & & & & \\
\hline \multirow{3}{*}{$\begin{array}{l}\text { Delta, } \\
\text { B.1.617.2 }\end{array}$} & \multirow{3}{*}{$\begin{array}{l}\text { India, } \\
\text { December } \\
2020\end{array}$} & L452R & $97 \%$ increase $^{69}$ & $92 \%$ effec- & Lower mean & Lower & No conclusive & Unknown & Unknown \\
\hline & & T478K & & $\begin{array}{l}\text { tive against } \\
\text { hospitalization }^{73}\end{array}$ & $\begin{array}{l}\text { plaque } \\
\text { reduction }\end{array}$ & $\begin{array}{l}\text { serum } \\
\text { neutraliza- }\end{array}$ & $\begin{array}{l}\text { evidence but } \\
\text { reports of } 60 \%\end{array}$ & & \\
\hline & & D614G & & one-dose & neutraliza- & tion titre & effectiveness ${ }^{75 a}$ & & \\
\hline
\end{tabular}

It is not possible to directly compare studies owing to differences in efficacy end points; the data are provided to give an overview of possible trends in the impact

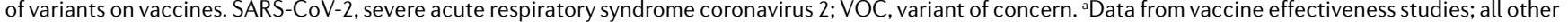
data for vaccine-mediated protection represent vaccine efficacy.

In Israel, which was one of the first countries to vaccinate a high proportion of the adult population and hence have a more comprehensive dataset regarding vaccine effectiveness, the national immunization programme started on 20 December 2020 using BNT162b2. Individuals at high risk of severe COVID-19 were prioritized before the vaccination programme was quickly expanded to include all individuals aged 16 years or older, with a view to reducing SARS-CoV-2 transmission. Initial data indicated a single-dose vaccine effectiveness against new infections of 51\% 13-24 days after immunization ${ }^{26}$. Viral load in infected individuals, as measured by reverse transcription-PCR for the SARS-CoV-2 $N$ and $S$ genes, was significantly lower in those who had been vaccinated than in unvaccinated individuals 12 days after vaccination $^{27}$. Another study estimated vaccine effectiveness for documented SARS-CoV- 2 infection at $46 \%$ after the first dose of BNT162b2 and $92 \%$ after the second dose $\mathrm{e}^{28}$, given at 3 weeks. Two doses of BNT162b2 were shown to reduce symptomatic cases of COVID-19 by $94 \%$ in a dataset of 1.2 million people $\mathrm{e}^{28}$.

In the USA, there was an $82 \%$ reduction of reverse transcription-PCR-positive new cases in vaccinated health-care workers versus unvaccinated healthcare workers 14 days after the first dose of either BNT162b2 or mRNA-1273 (REF. ${ }^{29}$ ). In another study, conducted between December 2020 and March 2021, vaccine effectiveness against infection after two doses of BNT162b2 or mRNA-1273 among health-care personnel was $90 \%{ }^{30}$. In a multistate analysis of adults aged
65 years or older receiving BNT162b2 or mRNA-1273, vaccine effectiveness against hospitalization for COVID-19 was 95\% after two doses and $64 \%$ after one dose ${ }^{31}$. Vaccine effectiveness against infection in a large cohort of 49,220 US health-care workers with a median age of 41 years exceeded $96 \%$ after two doses of BNT162b2 or mRNA-1273 (REF. ${ }^{32}$ ).

The efficacy data for the vaccines produced by Sinovac Biotech (CoronaVac) and Sinopharm (BBIBP-CorV) have not yet been published in a peer-reviewed journal, and similarly the vaccine effectiveness data for these vaccines are not available, even though the vaccines have Emergency Use Listing by the World Health Organization (WHO) and have been widely administered, particularly in low-income countries. Of concern, some countries with relatively 
high vaccination rates continue to have high levels of infection; for example, Chile, which has immunized $50 \%$ of the population $(87 \%$ of whom received CoronaVac), experienced 70,000 new cases a day in June 2021. A study conducted between February and May 2021 indicated that vaccine effectiveness was $66 \%$ for the prevention of laboratory-confirmed COVID-19 $\left(\right.$ REF $\left.^{33}\right)$. More openly available data are urgently required on the efficacy and effectiveness of these vaccines.

Taken together, the results show that where vaccine effectiveness data have been published, the findings are broadly consistent with efficacy data determined from clinical trials. Given the range of immune responses that are generated by different vaccine platforms, it will be essential to further understand what immune mechanism provides protection in each of these cases.

\section{Correlates of protection}

The mechanism of protection of COVID-19 vaccines is still not completely clear ${ }^{34}$. A measurable correlate of protection that reliably predicts protection against COVID-19 after vaccination or natural infection has not yet been defined. Better understanding of the mechanisms of protection will be important for comparing different vaccines and to accelerate the rollout of vaccines against future viral variants. Vaccination induces both humoral and cellular responses, but it is widely thought that vaccine-induced neutralizing antibodies to the receptor-binding domain of the SARS-CoV-2 S protein are a plausible mechanism of protection. Neutralizing antibodies to the $\mathrm{S}$ protein provide near-complete protection against rechallenge in animal studies ${ }^{35}$. Recent modelling studies have suggested that neutralizing antibodies are highly predictive of protection against infection or severe disease ${ }^{36}$, with a second modelling study suggesting a tight correlation between neutralizing antibody levels and reported efficacy across several COVID-19 vaccine trials ${ }^{18}$, and a third study derived from efficacy trials indicating that both binding and neutralizing antibody titres correlate with protection ${ }^{37}$.

Antibody-mediated protection reflects experience with influenza vaccines, and an assay measuring antibody function (equivalent to the haemagglutination inhibition assay used for influenza antibodies) will probably be the best tool to predict protection, as it is the easiest to standardize and distribute. However, the exact quality and quantity of vaccine-generated antigen-specific functional antibodies required to protect against SARS-CoV-2 reinfection in humans are not yet known. A combination of studies will be necessary to determine the best correlate of protection for SARS-CoV-2. One approach is to establish prospective cohorts of previously infected or vaccinated individuals and monitor these cohorts for subsequent SARS-CoV-2 infection; the banked material can then give an indication of levels of immunity that are not protective. This can be done in parallel with vaccine efficacy trials, comparing immune responses to vaccine in participants who develop COVID-19 with those who do not, although this requires there to be a relatively high vaccine failure rate. These studies can be combined with human challenge studies ${ }^{38}$,

\section{Box 1 | Adverse effects of COVID-19 vaccines}

Local or systemic minor acute reactions, such as injection pain, swelling and redness, or fatigue, fever, headaches and joint and muscle pain, are commonly reported after COVID-19 vaccination. A recent study exploring the combination of AZD1222 and BNT162b2 vaccines documented increased reactogenicity of heterologous prime-boost regimens compared with homologous vaccination ${ }^{76}$. The rollout of COVID-19 vaccines across multiple countries, targeting millions of recipients - significantly more than in the vaccine arms of the efficacy trials - has also seen cases of more severe adverse events, including anaphylaxis, myocarditis and thrombocytopenia.

Anaphylaxis

Sixty-six cases of anaphylaxis had been reported among 17,524,676 mRNA vaccinations in the USA as of February 2021 (REF. ${ }^{77}$ ). It is thought that this can be linked to polyethylene glycol-based components of these vaccines. Most cases were in women (63 of 66), of which $92 \%$ of patients received adrenaline as part of emergency treatment. No deaths have been reported from anaphylaxis following COVID-19 vaccination.

\section{Myocarditis}

In May 2021, several cases of heart inflammation (myocarditis and pericarditis) were reported through the US Centers for Disease Control and Prevention Vaccine Adverse Event Reporting System after vaccination with either BNT162b2 or mRNA-1273 (both mRNA vaccines). As of July 2021, 5,166 cases for BNT162b2 and 399 cases for mRNA-1273 among 129 million vaccinated individuals have been reported in the USA. Myocarditis cases have also been reported in Israel ${ }^{78}$.

\section{Vaccine-induced immune thrombotic thrombocytopenia}

In March 2021, the European Medicines Agency concluded that in an extremely small number of vaccinated individuals there is a causal link between AZD1222 administration, blood clotting and low platelet counts (thrombocytopenia), leading to 30 deaths in vaccinated individuals ${ }^{79}$. As a result, vaccine agencies in EU countries and the UK issued age-based restrictions on the use of AZD1222. Similarly, extremely rare events of thrombocytopenia were observed in the USA, with causality following Ad26.COV2-S vaccination ${ }^{80,81}$ (six deaths among more than 6.8 million vaccinated individuals). The FDA briefly paused use of Ad26.COV2-S in April 2021. Although it seems to be more strongly associated with adenovirus-based vaccines, thrombocytopenia has also been observed after mRNA vaccination ${ }^{82}$. The rates of vaccine-induced immune thrombotic thrombocytopenia (VITT) differ in different countries, with a higher rate reported in Scandinavia (1 in 10,000) than the UK ${ }^{83}$; regional differences may reflect HLA type, reporting sensitivity and pre-existing conditions ${ }^{84}$.

Analyses of 11 individual cases in Germany showed that VITT occurs some days after vaccination ${ }^{85}$, having characteristics of heparin-induced thrombocytopenia (HIT), with detectable levels of antibodies to the heparin-platelet factor 4 (PF4) complex $^{86}$. PF4 is a chemokine, also known as CXCL4, that promotes blood coagulation by binding heparin. In the related condition of HIT, antibodies bind the PF4-heparin complex and these antibody-bound complexes then bind platelets, leading to platelet activation and consumption ${ }^{87}$. Non-heparin anticoagulant agents are a suggested treatment for the condition, and intravenous immunoglobulin is recommended as a means to block the antibody Fc-mediated reaction ${ }^{88}$.

Why COVID-19 vaccines induce antibodies to PF4-heparin is less clear. It has been speculated that the antibodies are induced by vaccine vector-derived DNA. In vitro, PF4 can bind some constituents of the vaccine, and this complex can be recognized by antibodies raised from individuals with $\mathrm{VITT}^{99}$. Interestingly, adenoviruses themselves have been associated with a HIT-like disease in a mouse model ${ }^{90}$, which may explain the relative risk in the two adenovirus-based vaccines compared with the mRNA vaccines. The timing of the events - approximately 7 days after immunization - suggests that this rare reaction may not be a de novo response, but rather the boosting of some previously existing antibody, although this is still entirely speculative. Antibodies to PF4-heparin may be primed by previous exposure to severe acute respiratory syndrome coronavirus 2 (SARS-CoV-2), but a small cohort study suggests that this is not the case $^{91}$. More research, validated diagnostic tests and further guidance for treatment are warranted, yet the risk of cerebral venous thrombosis from VITT remains significantly lower following AZD1222 administration (estimated 5.0 per million) than from COVID-19 (39.0 (CI 25.2-60.2) per million) ${ }^{92}$. 
which allow direct testing of infection in individuals with known levels of pre-existing immunity. In early 2021, pilot SARS-CoV-2 human infection challenge studies were established at Imperial College London, UK, and the University of Oxford, UK, which will hopefully contribute to a better understanding of immune correlates. Neutralizing antibodies most likely have a protective role, but other mechanisms of antibody-mediated protection may also contribute, for example through the constant domain of the antibody such as antibody-dependent cell-mediated cytotoxicity, as well as cell-mediated immunity. One consideration regarding neutralizing antibodies is that they may be more sensitive to escape by viral variants as they target a focused region of the $S$ protein.

\section{Effects of viral variants}

Early in the COVID-19 pandemic, the number of 'mutant' variant viruses was low owing to the small number of people infected with the virus (and hence fewer opportunities for escape mutants to emerge). Since then, the huge number of infections, including prolonged infection in immunocompromised individuals, has led to the evolution of multiple SARS-CoV-2 variants. Understanding the impact of these variants on the success of public health and vaccination programmes is of paramount importance ${ }^{39}$. Although new variants continue to emerge, the most exhaustive information at present is on four variants of concern (VOCs); a VOC is defined by the $\mathrm{WHO}$ as a virus with mutations compared with the reference genome found in multiple clusters with either increased transmission or virulence or decreased impact of vaccines and therapeutics ${ }^{40}$. The VOCs were recently renamed by the WHO as Alpha (B.1.1.7), Beta (B.1.351), Gamma (P.1) and Delta (B.1.617.2). These strains predominantly have changes in the $S$ gene compared with the reference (Wuhan) strain (TABLE 2). The high frequency of mutations in the $S$ protein has caused global concern because these mutations could alter interactions with the host receptor ACE2, thereby changing the infection rate, or could modify the potency of neutralizing antibodies, thereby compromising vaccine efficacy. Here we discuss what we know so far about vaccine efficacy against these VOCs (TABLE 2).

Alpha (B.1.1.7) variant. So far, only low or no significant impact on vaccine effectiveness has been reported as a result of the B.1.1.7 variant. Only slight effects of some of the mutations present in the B.1.1.7 variant have been seen in virus neutralization studies using sera from BNT162b2-vaccinated individuals ${ }^{41}$. However, the modified virus used in this study lacked the full repertoire of S protein mutations from B.1.1.7 (REF. ${ }^{41}$ ). A significant reduction in neutralization titres in serum from BNT162b2-immunized individuals was observed with a pseudovirus that contains the complete set of B.1.1.7 mutations ${ }^{42}$. However, there was no significant impact on the neutralizing capacity of sera from humans or non-human primates who received mRNA-1273 against the B.1.1.7 variant ${ }^{43}$. Live virus neutralization activity of sera from AZD1222-immunized individuals was ninefold lower against the B.1.1.7 variant than against a canonical non-B.1.1.7 lineage ${ }^{44}$. Serum from individuals immunized with Ad26.COV2-S (Johnson \& Johnson) was able to neutralize the B.1.1.7 variant in vitro, although less efficiently than the reference strain ${ }^{45}$.

Although these in vitro studies have limitations regarding methodology and sample size or by considering only the humoral arm of the immune response, when taken together, they indicate that the efficacy of the vaccines should be similar or only slightly lower against the B.1.1.7 variant. This is supported by clinical studies. Novavax reports that its COVID-19 vaccine NVX-CoV2373, which includes the S protein from the SARS-CoV-2 Wuhan reference strain, has shown $86 \%$ efficacy against the B.1.1.7 variant ( $96 \%$ efficacy against the original strain) in a phase III clinical trial involving 15,000 participants aged between 18 and 84 years in the $\mathrm{UK}^{46}$. The effectiveness of AZD1222 against nucleic acid amplification test-positive infection with B.1.1.7 was $70 \%$, whereas for non-B.1.1.7 lineages, vaccine effectiveness was $77 \%{ }^{44}$.

Beta (B.1.351) variant. The $\mathrm{K} 417 \mathrm{~N}$ and E484K mutations in B.1.351 significantly affect the neutralization of this variant by both monoclonal antibodies and immune sera derived from convalescent patients ${ }^{47,48}$. B.1.351 is 6.5-fold more resistant than wild-type pseudovirus to neutralization by sera from individuals vaccinated with BNT162b2 (REF. ${ }^{49}$ ). A significant reduction in the neutralization of B.1.351 by sera from humans or non-human primates vaccinated with mRNA-1273 was also observed $^{43}$. Antibody responses and memory B cells from recipients of mRNA- 1273 or BNT162b2 showed decreased activity against SARS-CoV-2 variants containing E484K and N501Y mutations or the triple combination of K417N, E484K and N501Y (as found in B.1.351) ${ }^{50}$.
Whether this effect on antibody-mediated neutralization impacts vaccine-mediated protection is not fully known. The earliest indications come from clinical trials that have been conducted in populations where the new variants are circulating widely, although efficacy against viral variants is inferred mainly indirectly from VOC prevalence at the time of the trial. Interim efficacy results have been reported from two randomized placebo-controlled clinical trials conducted by Novavax and Johnson \& Johnson in South Africa. NVX-CoV2373 showed an efficacy of $49 \%$ against the B.1.351 variant in the prevention of mild, moderate and severe COVID-19 (REF. ${ }^{46}$ ), with efficacy increasing to $60 \%$ when HIV-positive individuals are excluded from the analysis ${ }^{46}$. In the ENSEMBLE trial by Johnson \& Johnson, the single-shot Ad26.COV2-S vaccine had 72\% efficacy against PCR-confirmed infection in the USA, but these values were reduced to 66\% efficacy in Latin America and 57\% efficacy in South Africa ${ }^{45}$, which may reflect a higher prevalence of B.1.351 in South Africa than in the USA. Ad26.COV2-S remained $85 \%$ effective overall in preventing severe COVID-19 across all regions ${ }^{51}$. The trial of AZD1222 in South Africa did not demonstrate protection against mild to moderate B.1.351-induced COVID-19; it is yet to be determined whether this vaccine offers protection against severe disease and death ${ }^{52}$.

Gamma (P.1) variant. Considering the high number of $S$ protein mutations that the P.1 variant has accumulated, it is reasonable to conclude that it will be equally or even more resistant than the B.1.351 variant to antibody-mediated protection. Laboratory serum neutralization assays using a pseudovirus have shown that the neutralizing activity of BNT162b2-elicited antibodies to B.1.1.7-spike virus and P.1-spike virus is approximately equivalent ${ }^{53}$. A trial in Brazil using the CoronaVac (Sinovac Biotech) vaccine showed an efficacy of $50 \%$ against symptomatic infection (just above the approval threshold for emergency use) in 12,508 volunteers, all of whom were health-care professionals in regular direct contact with SARS-CoV-2 (REF. ${ }^{54}$ ); however, infection with the P.1 variant was not confirmed but is assumed on the basis of the prevalence of circulating strains.

Delta (B.1.617.2) variant. A significant decrease in neutralizing antibody titre has been seen for B.1.617.2 compared with B.1.1.7 using sera from individuals 
immunized with BNT162b2. Vaccine effectiveness of $88 \%$ or $67 \%$ against symptomatic disease following infection with B.1.617.2 has been observed in England after two doses of BNT162b2 or AZD1222, respectively ${ }^{55}$. However, it was not possible to estimate the vaccine effectiveness against severe disease because at the time of the study (April to June 2021) there were few severe cases. Although the AZD1222 and BNT162b2 vaccines were both effective at reducing the risk of infection and hospitalization owing to B.1.617.2 in Scotland, the level of protection was not as high as against B.1.1.7 (REF. ${ }^{56}$ ).

In summary, across all the VOCs, a reduction of in vitro serum neutralization activity has been observed in highly sensitive assays, and there has been evidence of infection with VOCs in vaccinated populations, but the severity of disease is nevertheless much reduced, indicating that the vaccines are still highly effective. Prevention of severe disease, which could overwhelm hospitals and lead to death, is the most important goal of vaccination. Undoubtedly more VOCs will arise, and the impact of these on vaccine effectiveness is hard to predict; importantly at a time when total global vaccine coverage is low, increased transmission rather than vaccine escape is probably the main selective pressure.

\section{To boost or not to boost? To counteract the} impact of viral variants, one suggestion is to develop new vaccines that more closely reflect the circulating viruses. For example, Moderna has developed a novel vaccine targeting the B.1.1.7 VOC, which has been tested in preclinical trials ${ }^{57}$ and is now in

\section{Box 2 | Ongoing research questions for COVID-19 vaccines}

\section{How do the vaccines protect?}

What is the role of T cells in protection? Is there an easily measurable correlate of protection that can be used for future licensure? Is antibody-mediated protection due to mechanisms other than virus neutralization? What roles do $\lg \mathrm{A}$ and mucosal immunity have in protection?

\section{What kind of protection do the vaccines provide?}

Do the vaccines only prevent disease, or can they also prevent transmission or even asymptomatic infection? Although vaccination has been reported to reduce symptomatic COVID-19 cases, the direct evidence for vaccine-reduced transmission is limited. Reduced viral load has been observed in individuals vaccinated with BNT162b2, as measured by PCR Ct value ${ }^{27}$. As lower viral load has been associated with a reduction in onward transmission ${ }^{93}$, these data together suggest that vaccination could reduce transmission. Can vaccines give true 'sterilizing immunity' and should we even be aiming for sterilizing immunity in a pandemic situation or just protection against severe disease?

How broadly effective are the current vaccines against viral variants of concern? Will there be a need for booster vaccines? How much antigenic distance between vaccine antigens is required to avoid original antigenic sin? Are conserved epitopes in the severe acute respiratory syndrome coronavirus 2 (SARS-CoV-2) spike protein sufficient to protect against infection with variants, which could set the stage for a more universal vaccine?

Is vaccine-mediated protection in low-income and middle-income countries equivalent to that in high-income countries?

What is the impact of pre-existing infections such as HIV-1 infection? Could other systemic co-infections reduce the efficacy of mRNA vaccines by preventing translation? Is there any cause for concern about using the adenovirus serotype 5 vector, for example as used in the Sputnik V vaccine from Gamaleya, in the context of the STEP HIV-1 vaccine study? Post hoc analysis of this study suggested that more HIV-1 infections occurred in vaccine recipients than in placebo-receiving controls, with a suggestion that this was in some way caused by the adenovirus serotype 5 vaccine platform ${ }^{94}$

\section{How can vaccine rollout be accelerated?}

What is the best way to increase global production of vaccines? How can the flow of raw material be increased? How can the number of qualified people to oversee good manufacturing practice be increased? What can research do to help here, for example in terms of fractional dosing, mix-and-match vaccines, and improvements in vaccine formulation and adjuvants?

What are the lessons from this pandemic for future outbreaks?

Will the vaccine platforms that are so effective against SARS-CoV-2 provide similar protection against other pathogens? How important is pathogen-specific research versus a more general understanding of viruses?

What is the impact of age on the immune response to vaccines?

Because of the greater impact of COVID-19 in elderly people, the focus so far has been on this age group, but will the same vaccine platforms be as effective in children and adolescents for future pandemics?

clinical trials (NCT04785144). However, it is not clear how beneficial such vaccines designed specifically to target new variants will be. The main consideration will be how far the circulating viruses in autumn 2021 (when booster vaccination has been proposed in some countries) will have drifted antigenically from the original reference sequence of the SARS-CoV-2 $S$ protein used for the first-generation vaccines. Although studies relating to the VOCs have shown reduced neutralization in vitro, there has been no significant reported impact on vaccine effectiveness, which suggests that the viral mutations predominantly increase transmissibility, but not necessarily immune escape. As the current vaccines still offer good protection against severe disease, there may be limited return on a new variant booster. Indeed, there may actually be negative unintended consequences. The first is that producing a new booster vaccine for the countries with sufficient income to afford substantial coverage with the first-generation vaccines may reduce manufacturing capacity for doses for lower-income countries. Second, boosting with a similar antigen may boost the antibody response to the original strain rather than prime for antibodies specific to the new strain ${ }^{58}$. This idea of 'original antigenic sin' refers to the boosting of responses to previously seen epitopes to the detriment of responses to new epitopes, particularly when they are closely related. Such a phenomenon has been observed for influenza, with individuals who were recently immunized with seasonal influenza vaccine producing lower antibody responses to 2009 pandemic influenza than previously unimmunized individuals ${ }^{59}$. Furthermore, the variants may be drifting apart, and so priming with a variant might narrow rather than broaden protection. It is our opinion that engineering novel booster vaccines should not be a priority at this time.

Whereas engineering new variant vaccines may not be beneficial, an alternative strategy is to boost immunity with a third dose of vaccine targeting the initial reference strain. One important consideration is how rapidly and to what extent immunity wanes after vaccination. There were initially concerns that immunity would wane rapidly, but recent studies have observed sustained B cell-mediated immunity 12 months after initial infection ${ }^{60,61}$, although other components of the immune response, such as $\mathrm{T}$ cell responses, may wane faster ${ }^{62}$. However, there may still be benefits to an additional booster dose of vaccine. Whether this should be with the 
same vaccine as used for the initial course or with a heterologous platform is not yet known, and studies are ongoing to explore the impact of heterologous prime-boost vaccination on immunity. There are also important considerations about equity - if individuals in lower-income countries have not yet received any vaccine doses, is it fair to offer booster vaccination to individuals in higher-income countries?

\section{Deployment issues}

The challenge to increase vaccine coverage is twofold: overcoming vaccine hesitancy in the countries that do have access to vaccines but are being slow to distribute them and getting vaccine stock to countries in need. In some countries, vaccine hesitancy is clearly a challenge, with variable rates of vaccine uptake both between countries and within different populations in the same country ${ }^{63}$. Hesitancy (or no hesitancy) regarding vaccination is changing almost as quickly as the vaccine trial landscape, and live resources such as the Vaccine Confidence Project provide updated coverage.

Compared with vaccine hesitancy, global vaccine equity and access is the far bigger hurdle. There is no quick fix to increase global vaccine supply, which involves issues of reagent supply, qualified manufacturing staff, manufacturing capacity, regulatory hurdles and distribution, even without the larger context of vaccine nationalism. One problem that has been discussed prominently is intellectual property. In early May 2021, the USA proclaimed support for waiving COVID-19 vaccine patents ${ }^{64}$. Unfortunately, waiving intellectual property rights is unlikely to overcome any of the problems described. Should COVID-19 vaccine patents be lifted, there are still major hurdles regarding technology transfer, training and good manufacturing practice regulations required to produce vaccines with sufficient quality, while regulators would require safety and efficacy trials to be completed for unique products. Because vaccines are complex biological products, licensure and partnership agreements may be a more effective route to increase supply, so that technical know-how and cell seed stocks can be shared; for example, as AstraZeneca has done with the Serum Institute of India. The most important step now is to send vaccines to the countries that need them the most, prioritizing the most at risk on a global level rather than a national level. One of the key lessons from this pandemic is that a more globally distributed vaccine manufacturing infrastructure is required.

\section{Conclusions}

There are still many questions posed by the COVID-19 vaccine effort that need to be addressed, both in the context of this pandemic and for future pandemics (BOX 2). The development and deployment of vaccines for COVID-19 is a remarkable science success story: within 16 months of the first vaccine trials, 2.8 billion vaccine doses have been administered. A crucial question is whether this success can be replicated in future pandemics. Pre-existing investment in vaccine platform technologies was crucial for the speed of the response: three of the most rapidly approved vaccines (BNT162b2, mRNA-1273 and AZD1222) use novel technologies. mRNA vaccines had never been tested in an efficacy trial for infectious disease before 2020, and viral vectors had been successfully deployed only against Ebola virus. Interestingly and despite concerns about vaccine-induced disease enhancement, the other vaccine platform to be rapidly developed was a much older technology - viral inactivation as used in CoronaVac and BBIBP-CorV. This platform-specific approach was important in accelerating the development of SARS-CoV-2 vaccines; whether the same platforms will work for all pathogens is not known, so maintaining a broad portfolio of platforms will be necessary. Having multiple vaccine platforms available also led to more vaccines in the pipeline and therefore a greater manufacturing capacity. Another important factor was the ability to transfer understanding from similar pathogens: AZD1222 was developed from a Middle East respiratory syndrome coronavirus programme, and the protein engineering approach used to stabilize the $S$ protein was derived from understanding of the respiratory syncytial virus fusion glycoprotein and the difference between prefusion and postfusion states, which was made possible only through long-term investment. Faster responses came from smaller biotechnology companies and academic institutions (with support from larger companies to scale up); whether this reflects a nimbler response or a different risk profile is unclear. All of these considerations lead to a conclusion that a broad research base is the best approach to prepare for an unknown future pathogen. As a final note, most of the COVID-19 vaccine doses have been administered in high-income or middle-income countries; as of June 2021 , only $0.9 \%$ of people in low-income countries had received at least one dose (Our World in Data). In parallel with ongoing investment in research, investment in manufacturing capacity, training and the ability to deliver vaccines globally is crucial to build on the incredible successes of the past 18 months.

John S. Tregoning $\mathrm{ID}^{凶}$, Katie E. Flight, Sophie L. Higham, Ziyin Wang (D) and Benjamin F. Pierce iD

Department of Infectious Disease, St Mary's Campus, Imperial College London, London, UK.

凶e-mail: john.tregoning@imperial.ac.uk https://doi.org/10.1038/s41577-021-00592-1

Published online 9 August 2021

1. Mathieu, E. et al. A global database of COVID-19 vaccinations. Nat. Hum. Behav. https://doi.org/ 10.1038/s41562-021-01122-8 (2021).

2. Polack, F. P. et al. Safety and efficacy of the BNT 162 b2 mRNA Covid-19 vaccine. N. Engl. J. Med. 383, 2603-2615 (2020)

3. Baden, L. R. et al. Efficacy and safety of the mRNA-1 273 SARS-CoV-2 vaccine. N. Engl. J. Med. 384, 403-416 (2021)

4. Voysey, M. et al. Single-dose administration and the influence of the timing of the booster dose on immunogenicity and efficacy of ChAdOx $1 \mathrm{nCoV}-19$ (AZD 1222) vaccine: a pooled analysis of four randomised trials. Lancet 397, 881-891 (2021).

5. National Institutes of Health. Janssen investigational COVID-19 vaccine: interim analysis of phase 3 clinical data released. https://www. nih.gov/news-events/ news-releases/janssen-investigational-covid-19vaccine-interim-analysis-phase-3-clinical-data-released (2021).

6. Logunov, D. Y. et al. Safety and efficacy of an rAd26 and $\mathrm{rAd} 5$ vector-based heterologous prime-boost COVID-19 vaccine: an interim analysis of a randomised controlled phase 3 trial in Russia. Lancet 397. 671-681 (2021).

7. Kim, J. H., Marks, F. \& Clemens, J. D. Looking beyond COVID-19 vaccine phase 3 trials. Nat. Med. 27, 205-211 (2021).

8. Novavax. Novavax COVID-19 vaccine demonstrates 89.3\% efficacy in UK phase 3 trial | Novavax Inc. - IR site. https://ir.novavax.com/news-releases/news-release details/novavax-covid-19-vaccine-demonstrates-893efficacy-uk-phase-3 (2021)

9. Bharat Biotech. Bharat biotech announces phase 3 results of COVAXIN ®: India's first COVID - 19 vaccine demonstrates interim clinical efficacy of $81 \%$ https://www.bharatbiotech.com/images/press/covaxinphase3-efficacy-results.pdf (2021).

10. IAVI. IAVI and Merck discontinue development of V590 - IAVI. https://www.iavi.org/news-resources/pressreleases/2021/merck-and-iavi-discontinue-development of-covid-19-vaccine-candidate-v590 (2021).

11. Merck. Merck discontinues development of SARS-CoV-2/COVID-19 vaccine candidates; continues development of two investigational therapeutic candidates. https://www. merck.com/news/merckdiscontinues-development-of-sars-cov-2-covid-19 vaccine-candidates-continues-development-of-twoinvestigational-therapeutic-candidates/ (2021).

12. CSL. Update on the University of Queensland COVID-19 vaccine. https://www.csl.com/news/2020/20 201211-update-on-the-university-of-queenslandcovid-19-vaccine (2020).

13. The University of Queensland. Molecular clamp vaccines: lessons from a setback. https://www.nature. $\mathrm{com} /$ articles/d42473-020-00504-2? source= globalbiodefense (2021).

14. CureVac. Curevac provides update on phase $2 b / 3$ trial of first-generation COVID-19 vaccine candidate. https://www.curevac.com/en/2021/06/16/curevacprovides-update-on-phase-2b-3-trial-of-firstgeneration-covid-19-vaccine-candidate-cvncov/ (2021).

15. Dolgin, E. CureVac COVID vaccine let-down spotlights mRNA design challenges. Nature $594,483-483$ (2021).

16. GSK. Sanofi and GSK announce a delay in their adjuvanted recombinant protein-based COVID-19 vaccine programme to improve immune response in the elderly. https://www.gsk.com/en-gb/media/ press-releases/sanofi-and-gsk-announce-a-delay-intheir-adjuvanted-recombinant-protein-based-covid-19 vaccine-programme-to-improve-immune-responsein-the-elderly/ (2020). 
17. McDonald, I., Murray, S. M., Reynolds, C. J., Altmann, D. M. \& Boyton, R J Comparative systematic review and meta-analysis of reactogenicity, immunogenicity and efficacy of vaccines against SARS-CoV-2. NPJ Vaccines 6, 1-14 (2021).

18. Earle, K. A. et al. Evidence for antibody as a protective correlate for COVID-19 vaccines. Vaccine https://doi.org/10.1016/j.vaccine.2021.05.063 (2021).

19. Public Health England. Public Health England vaccine effectiveness report. https://assets. publishing.service. gov.uk/government/uploads/system/uploads/ attachment_data/file/989360/PHE_COVID-19_vaccine effectiveness_report_March_2021_v2.pdf (2021).

20. Bernal, J. L. et al. Effectiveness of the Pfizer-BioNTech and Oxford-AstraZeneca vaccines on covid-19 related symptoms, hospital admissions, and mortality in older adults in England: test negative case-control study. BMJ 373, n1088 (2021)

21. Hall, V. J. et al. COVID-19 vaccine coverage in health-care workers in England and effectiveness of BNT162b2 mRNA vaccine against infection (SIREN): a prospective, multicentre, cohort study. Lancet 397 , 1725-1735 (2021)

22. Pimenta, D., Yates, C., Pagel, C. \& Gurdasani, D. Delaying the second dose of covid-19 vaccines. $B M J$ 372, n710 (2021).

23. Wei, J. et al. The impact of SARS-CoV-2 vaccines on antibody responses in the general population in the United Kingdom. Preprint at medRxiv https://doi.org/ 10.1101/2021.04.22.21255911 (2021).

24. Vasileiou, $E$. et al. Interim findings from firstdose mass COVID-19 vaccination roll-out and COVID-19 hospital admissions in Scotland: a national prospective cohort study. Lancet 397, 1646-1657 (2021).

25. Parry, H. et al. Extended interval BNT162b2 vaccination enhances peak antibody generation in older people. Preprint at medRxiv https://doi.org/ 10.1101/2021.05.15.21257017 (2021).

26. Mahase, E. Covid-19: Israel sees new infections plummet following vaccinations. BMJ 372, n338 (2021).

27. Levine-Tiefenbrun, M. et al. Initial report of decreased SARS-CoV-2 viral load after inoculation with the BNT162b2 vaccine. Nat. Med. 27, 198-199 (2021).

28. Shilo, S., Rossman, H. \& Segal, E. Signals of hope: gauging the impact of a rapid national vaccination campaign. Nat. Rev. Immunol. 21, 198-199 (2021).

29. Bouton, T. C. et al. COVID-19 vaccine impact on rates of SARS-CoV-2 cases and post vaccination strain sequences among healthcare workers at an urban academic medical center: a prospective cohort study. Preprint at medRxiv https://doi.org/10.1101/ 2021.03.30.21254655 (2021).

30. Thompson, M. G. et al. Interim estimates of vaccine effectiveness of BNT162b2 and mRNA-1273 COVID-19 vaccines in preventing SARS-CoV-2 infection among health care personnel, first responders, and other essential and frontline workers - eight U.S locations, December 2020-March 2021. MMWR 70, 495-500 (2021).

31. Tenforde, M. W. et al. Effectiveness of Pfizer-BioNTech and Moderna vaccines against COVID-19 among hospitalized adults aged $\geq 65$ years - United States, January-March 2021. MMWR 70, 674-679 (2021).

32. Swift, M. D. et al. Effectiveness of mRNA COVID-19 vaccines against SARS-CoV-2 infection in a cohort of healthcare personnel. Clin. Infect. Dis. https://doi.org/ 10.1093/cid/ciab361 (2021)

33. Jara, A. et al. Effectiveness of an inactivated SARS-CoV-2 vaccine in Chile. N. Engl. J. Med. https://doi.org/10.1056/NEJMoa2107715 (2021)

34. Moghadas, S. M. et al. Evaluation of COVID-19 vaccination strategies with a delayed second dose. PLoS Biol. 19, e3001211 (2021).

35. Jin, P., Li, J., Pan, H., Wu, Y. \& Zhu, F. Immunological surrogate endpoints of COVID-2019 vaccines: the evidence we have versus the evidence we need. Signal. Transduct Target Ther 6, 1-6 (2021).

36. Khoury, D. S. et al. Neutralizing antibody levels are highly predictive of immune protection from symptomatic SARS-CoV-2 infection. Nat. Med. https://doi.org/10.1038/s41591-021-01377-8. (2021).

37. Feng, S. et al. Correlates of protection against symptomatic and asymptomatic SARS-CoV-2 infection. Preprint at medRxiv https://doi.org 10.1101/2021.06.21.21258528 (2021).
38. Huang, A. T. et al. A systematic review of antibody mediated immunity to coronaviruses: kinetics, correlates of protection, and association with severity. Nat. Commun. 11, 1-16 (2020).

39. Gupta, R. K. Will SARS-CoV-2 variants of concern affect the promise of vaccines? Nat. Rev. Immunol. 21, 340-341 (2021)

40. World Health Organization. Tracking SARS-CoV-2 variants. https://www.who.int/en/activities/trackingSARS-CoV-2-variants/ (2021).

41. Xie, X. et al. Neutralization of SARS-CoV-2 spike $69 / 70$ deletion, E484K and N501Y variants by BNT162b2 vaccine-elicited sera. Nat. Med. 27 620-621 (2021)

42. Muik, A. et al. Neutralization of SARS-CoV-2 lineage B.1.1.7 pseudovirus by BNT162b2 vaccine-elicited human sera. Science 371, 1152-1153 (2021).

43. Wu, K. et al. mRNA-1273 vaccine induces neutralizing antibodies against spike mutants from global SARS-CoV-2 variants. Preprint at bioRxiv https://doi.org 10.1101/2021.01.25.427948 (2021).

44. Emary, K. R. W. et al. Efficacy of ChAdOx 1 nCoV-19 (AZD 1222) vaccine against SARS-CoV-2 variant of concern 202012/01 (B.1.1.7): an exploratory analysis of a randomised controlled trial. Lancet 397, 1351-1362 (2021)

45. Sadoff, J et al. Safety and efficacy of single-dose Ad26.COV2.S vaccine against Covid-19. N. Engl. J. Med. 384, 2187-2201 (2021)

46. Callaway, E. \& Mallapaty, S. Novavax offers first evidence that COVID vaccines protect people against variants. Nature 590, 17 (2021)

47. Wang, Z. et al. mRNA vaccine-elicited antibodies to SARS-CoV-2 and circulating variants. Nature 592 , 616-622 (2021)

48. Wang, P. et al. Antibody resistance of SARS-CoV-2 Variants B.1.351 and B.1.1.7. Nature https://doi.org 10.1038/s41586-021-03398-2 (2021).

49. Ho, D. et al. Increased resistance of SARS-CoV-2 variants B. 1.351 and B. 1.1.7 to antibody neutralization. Res. Sq https://doi.org/10.21203/rs.3.rs-155394/v1 (2021).

50. Wibmer, C. K et al. SARS-CoV-2 501Y.V2 escapes neutralization by South African COVID-19 donor plasma. Nat. Med. 27, 622-625 (2021).

51. Ledford, H. J\&J's one-shot COVID vaccine offers hope for faster protection. Nature https://doi.org/10.1038/ d41586-021-00119-7. (2021).

52. Voysey, M. et al. Safety and efficacy of the ChAdOx 1 $n C o V-19$ vaccine (AZD 1222) against SARS-CoV-2: an interim analysis of four randomised controlled trials in Brazil, South Africa, and the UK. Lancet 397, 99-111 (2021).

53. Liu, Y. et al. Neutralizing activity of BNT162b2-elicited serum. N. Engl. J. Med. https://doi.org/10.1056/ nejmc2102017 (2021).

54. Mallapaty, S. China COVID vaccine reports mixed results - what does that mean for the pandemic? Nature https://doi.org/10.1038/d41586-021-00094-z (2021).

55. Wall, E. C. et al. Neutralising antibody activity against SARS-CoV-2 VOCs B.1.617.2 and B.1.35 by BNT162b2 vaccination. Lancet 397, 2331-2333 (2021).

56. Sheikh, A., McMenamin, J., Taylor, B. \& Robertson, C. SARS-CoV-2 Delta VOC in Scotland: demographics, risk of hospital admission, and vaccine effectiveness. Lancet 397, 2461-2462 (2021).

57. $\mathrm{Wu}, \mathrm{K}$, et al. Variant SARS-CoV-2 mRNA vaccines confer broad neutralization as primary or booster series in mice. Preprint at bioRxiv https://doi.org/ 10.1101/2021.04.13.439482 (2021).

58. Noori, M. et al. "Original antigenic sin": a potential threat beyond the development of booster vaccination against novel SARS-CoV-2 variants. Infect. Control. Hospital Epidemiol. https://doi.org/10.1017/ ice.2021.199 (2021)

59. Choi, Y. S. et al. Reduced antibody responses to the pandemic (H1N1) 2009 vaccine after recent seasonal influenza vaccination. Clin. Vaccine Immunol. 18 1519-1523 (2011)

60. Turner, J. S. et al. SARS-CoV-2 infection induces long-lived bone marrow plasma cells in humans Nature https://doi.org/10.1038/s41586-021-03647-4 (2021).

61. Wang, Z. et al. Naturally enhanced neutralizing breadth against SARS-CoV-2 one year after infection. Nature https://doi.org/10.1038/s41586-021-03696-9 (2021).

62. Tomic, A. et al. Divergent trajectories of antiviral memory after SARS-Cov-2 infection. Rs. Sq https://doi.org/10.21203/RS.3.RS-612205/V1 (2021).
63. Lazarus, J. V. et al. Hesitant or not? The association of age, gender, and education with potential acceptance of a COVID-19 vaccine: a country-level analysis. J. Health Commun. 25, 799-807 (2020).

64. United States Trade Representative. Statement from Ambassador Katherine Tai on the Covid-19 TRIPS waiver. https://ustr.gov/about-us/policy-offices/pressoffice/press-releases/2021/may/statement-ambassador katherine-tai-covid-19-trips-waiver (2021)

65. Mahase, E. Covid-19: Novavax vaccine efficacy is $86 \%$ against UK variant and $60 \%$ against South African variant. BMJ 372, n296 (2021).

66. Graham, M. S. et al. Changes in symptomatology, reinfection, and transmissibility associated with the SARS-CoV-2 variant B. 1.1.7: an ecological study. Lancet Public Heal. 6, e335-e345 (2021).

67. Abu-Raddad, L. J., Chemaitelly, H., Butt, A. A. \& National Study Group for COVID-19 Vaccination. Effectiveness of the BNT162b2 Covid-19 vaccine against the B.1.1.7 and B.1.351 Variants. N. Engl. J. Med. https://doi.org/10.1056/NEJMc2104974 (2021).

68. Wu, K. et al. Serum neutralizing activity elicited by mRNA-1273 vaccine. N. Engl. J. Med. 384 , 1468-1470 (2021).

69. Campbell, F. et al. Increased transmissibility and global spread of SARS-CoV-2 variants of concern as at June 2021. Euro Surveill. 26, 2100509 (2021).

70. Madhi, S. A. et al. Efficacy of the ChAdOx $1 \mathrm{nCoV}-19$ Covid-19 vaccine against the B. 1.351 variant. N. Engl. J. Med. https://doi.org/10.1056/nejmoa2102214 (2021).

71. Faria, N. R. et al. Genomics and epidemiology of the P. 1 SARS-CoV-2 lineage in Manaus, Brazil. Science 372, 815-821 (2021).

72. De Faria, $E$ et al. Performance of vaccination with CoronaVac in a cohort of healthcare workers (HCW) - preliminary report. Preprint at medRxiv https://doi.org/10.1101/2021.04.12.21255308 (2021).

73. Liu, J. et al. BNT162b2-elicited neutralization of B. 1.617 and other SARS-CoV-2 variants. Nature https://doi.org/10.1038/s41586-021-03693-y (2021).

74. Stowe, J. et al. Effectiveness of COVID-19 vaccines against hospital admission with the Delta (B. 1.617.2) variant. Public Health England https://khub.net/web/ phe-national/public-library/-/document_library/ v2WsRK3ZIEig/view/479607266 (2021).

75. CBS News. Delta variant of COVID-19 likely to become dominant U.S. strain, Gottlieb says - CBS News. https://www.cbsnews.com/news/covid-19-deltavarient-dominant-strain-likely/ (2021).

76. Shaw, R. H. et al. Heterologous prime-boost COVID-19 vaccination: initial reactogenicity data. Lancet 397 2043-2046 (2021).

77. Shimabukuro, T. T., Cole, M. \& Su, J. R. Reports of anaphylaxis after receipt of mRNA COVID-19 vaccines in the US-December 14, 2020-January 18, 2021 JAMA 325, 1101-1102 (2021).

78. Larson, K. F. et al. Myocarditis after BNT $162 \mathrm{~b} 2$ and mRNA-1273 vaccination. Circulation https://doi.org/ 10.1161/CIRCULATIONAHA. 121.055913 (2021).

79. European Medicines Agency. DHPC: COVID-19 vaccine AstraZeneca: risk of thrombocytopenia and coagulation disorders. https://www.ema.europa.eu/en medicines/dhpc/vaxzevria-previously-covid-19-vaccineastrazeneca-risk-thrombocytopenia-coagulationdisorders (2021)

80. Food and Drug Administration. Joint CDC and FDA statement on Johnson \& Johnson COVID-19 vaccine. https://www.fda.gov/news-events/press-announcements/ joint-cdc-and-fda-statement-johnson-johnson-covid-19vaccine (2021)

81. Shay, D. K. et al. Safety monitoring of the Janssen (Johnson \& Johnson) COVID-19 vaccine - United States, March-April 2021. MMWR 70, 680-684 (2021).

82. Lee, E. J. et al. Thrombocytopenia following Pfizer and Moderna SARS-CoV-2 vaccination. Am. J. Hematol. https://doi.org/10.1002/ajh.26132 (2021)

83. Pottegård, A et al Arterial events, venous thromboembolism, thrombocytopenia, and bleeding after vaccination with Oxford-AstraZeneca ChAdOx 1-S in Denmark and Norway: Population based cohort study. BMJ 373, n1114 (2021).

84. Chan, B. T. et al. Meta-analysis of risk of vaccine-induced immune thrombotic thrombocytopenia following ChAdOx 1-S recombinant vaccine. Preprint at medRxiv https://doi.org/10.1101/2021.05.04.21256613 (2021). 


\section{PROGRESS}

85. Greinacher, A. et al. Thrombotic thrombocytopenia after ChAdOx1 nCov-19 vaccination. N. Engl. J. Med. https://doi.org/10.1056/NEJMoa2104840 (2021).

86. Scully, M. et al. Pathologic antibodies to platelet factor 4 after ChAdOx1 nCoV-19 vaccination. N. Engl. J. Med. https://doi.org/10.1056/NEJMoa2105385 (2021).

87. Reilly, R. F. Heparin-induced thrombocytopenia in dialysis: the pathophysiology of immune-mediated heparin-induced thrombocytopenia. Semin. Dial. 16 54-60 (2003).

88. British Society for Haematology. Guidance produced from the Expert Haematology Pane (EHP) focussed on Covid-19 vaccine induced thrombosis and thrombocytopenia (VITT). https://b-s-h. org.uk/about-us/news/guidance-produced-by-theexpert-haematology-panel-ehp-focussed-on-vaccineinduced-thrombosis-and-thrombocytopenia-vitt (2021).

89. Greinacher, A. et al. Towards understanding ChAdOx 1 nCov-19 vaccine-induced immune thrombotic thrombocytopenia (VITT). Rs Sq. https://doi.org 10.21203/rs.3.rs-440461/v1 (2021).

90. Othman, M., Labelle, A., Mazzetti, I., Elbatarny, H. S. \& Lillicrap, D. Adenovirus-induced thrombocytopenia: the role of von Willebrand factor and P-selectin in mediating accelerated platelet clearance. Blood 109 , 2832-2839 (2007).

91. Greinacher, A. et al. Anti-SARS-CoV-2 spike protein and anti-platelet factor 4 antibody responses induced by COVID-19 disease and ChAdOx 1 nCov-19 vaccination. Research Square https://doi.org/10.21203 rs.3.rs-404769/v1 (2021).

92. Devasagayam, S., Wyatt, B., Leyden, J. \& Kleinig, T. Cerebral venous sinus thrombosis incidence is higher than previously thought: a retrospective population-based study. Stroke 47, 2180-2182 (2016).

93. Kawasuji, H. et al. Transmissibility of COVID-19 depends on the viral load around onset in adult and symptomatic patients. PLOS ONE 15, e0243597 (2020).

94. Duerr, A. et al. Extended follow-up confirms early vaccine-enhanced risk of HIV acquisition and demonstrates waning effect over time among participants in a randomized trial of recombinant adenovirus HIV vaccine (Step Study). J. Infect. Dis. 206, 258-266 (2012).

Acknowledgements

The authors thank C. Weller for helpful discussion.

Author contributions

The authors contributed equally to all aspects of the article.
Competing interests

B.F.P. is funded by the UK Department of Health and Social Care using UK Aid funding, managed by the Engineering and Physical Sciences Research Council (grant number $\mathrm{EP} / \mathrm{R} 013764 / 1)$. The views expressed in this publication are those of the authors and not necessarily those of the Department of Health and Social Care.

\section{Peer review information}

Nature Reviews Immunology thanks J. Cramer and the other, anonymous, reviewer(s) for their contribution to the peer review of this work.

\section{Publisher's note}

Springer Nature remains neutral with regard to jurisdictional claims in published maps and institutional affiliations.

\section{RELATED LINKS}

ClinicalTrials.gov: https://clinicaltrials.gov/

COVID-19 Vaccine Tracker: https://vac-lshtm.shinyapps.io/ ncov_vaccine_landscape/

Our World in Data: Coronavirus (COVID-19) Vaccinations:

https://ourworldindata.org/covid-vaccinations

Vaccine Confidence Project: https://www.vaccineconfidence.org/

(C) Springer Nature Limited 2021 